\title{
CAPÍTULO 4
}

\section{DOUTOMANIA, CONHECIMENTO E PERFORMANCE EM O HOMEM QUE SABIA JAVANÊS, DE LIMA BARRETO}

Valéria Angélica Ribeiro Arauz ${ }^{22}$

\section{RESUMO}

A obra literária nasce também como resposta à realidade circundante ao seu autor. Na sala de aula, ela pode servir como um meio de reflexão acerca do mundo do leitor, a partir daquele mundo criado, como também acerca das relações humanas que perduram ao longo do tempo e atravessam os mais diversos contextos, evidenciando o que há de melhor e pior nas pessoas. No Rio de Janeiro do início do Século XX, Lima Barreto denuncia em suas obras uma postura social a que ele pejorativamente denominou "doutomania". Nesta análise, lemos o conto "O homem que sabia javanês" em uma perspectiva da construção textual com vistas a configurar um leitor-modelo (ou leitor implícito) construído pelo autor para que perceba como, na sociedade brasileira desse período, a performance parece ser mais valorizada que o conhecimento em si. Para tanto, tomamos as teorias relacionadas à construção de Mundos Ficcionais e ao Leitor de Italo Calvino (1995), Wolfgang Iser (1996) e Umberto Eco (2002, 2004). Como resultado, observamos

\footnotetext{
22 Doutora em estudos Literários pela Unesp. Docente da UFMA. E-mail: valeriaarauz@ gmail.com.
} 
que, além da ironia, o conto revela como funcionam os processos de utilização do conhecimento em uma época de valoração de posturas academicistas.

Palavras-chave: Lima Barreto; Mundos Ficcionais; Leitor.

\section{INTRODUÇ̄̃̃O}

Vivemos em um tempo cujo conhecimento científico é não somente aclamado, mas valorizado em um nível que beira o dogmatismo. Para figurar no noticiário brasileiro, muitos se arvoram de especialistas em diversos assuntos e, recentemente, têm crescido os casos no país em que pessoas forjam seus títulos acadêmicos - muitas vezes em instituições de renome internacional - para ganhar destaque no cenário político e social.

Esse comportamento, porém, não é algo da nossa contemporaneidade. Ele está presente na construção nacional do Brasil e pode ser observado desde a época colonial. Do período imperial ao início da República, ele se manifestou predominantemente em um fenômeno conhecido como "bacharelismo". Segundo essa prática, por causa do crescimento da máquina estatal no império, principalmente na segunda metade do século XIX, os egressos das faculdades de Direito assumiam no país diversas funções burocráticas, com vistas a prover os cargos à época abundantes nas repartições públicas do país (LOPES, 2010; SONTAG, 2008), muitas das quais sem qualquer relação com a sua área de formação (JARDIM, 2010; LOPES, 2010; MÜGGE; CONTE; HENGEN, 2018). Essa realidade foi examinada, combatida e muitas vezes satirizada pelos escritores da época em seus textos, ficcionais ou não. Sontag (2008) descreve esse período e nos dá um exemplo dessa crítica a partir da obra de Monteiro Lobato, quando cita:

Por instinto de conservação é força, pois, que o bacharel - Triatoma baccalaureatus - entregue o cetro da governança ao higienista, para que este, aliado ao engenheiro, conserte a máquina brasílica, desengonçada pela ignorância enciclopédica do rubim (LOBATO, 1971, p. 133 apud SONTAG, 2008, p. 68).

Nesse trecho, o autor de Urupês associa o bacharel a uma praga, uma vez que "triatoma" é uma referência à praga do inseto barbeiro, e aponta para uma resposta que aconteceu no início do século XX: a substituição dos bacharéis de direito por profissionais de outras formações mais específicas relacionadas às suas funções, como o higienista Oswaldo Cruz e o engenheiro Pereira Passos.

Lima Barreto também se mostrou contrário ao bacharelismo em várias de suas obras. Há referências críticas a essa prática sob o termo forjado pela 
própria obra barretiana: a "doutomania". Ela se apresenta em obras como em Triste Fim de Policarpo Quaresma, Recordações do Escrivão Isaías Caminha, Os Bruzundangas, entre outras. Lopes (2010) demonstra como a percepção do escritor associava essa característica da sociedade brasileira a algo pejorativo. A autora apresenta esse cenário conforme depreendido dos romances já citados:

Essa sua visão crítica desemboca numa percepção particularmente acurada e demolidora do valor atribuído pela sociedade brasileira aos portadores de título superior.

A rigor, um estudante do curso de Direito, por exemplo, concluído seu curso de quatro ou cinco anos, se tornaria bacharel e, caso defendesse a tese de doutorado seria, então, doutor. No entanto, vamos encontrar certa indiferenciação entre esses dois títulos na sociedade, conforme pode ser depreendido em suas obras.

Lima Barreto cunhou o termo "doutomania" para expressar a ideologia de valorização do título, vigente na sociedade da sua época, também conhecida como "bacharelismo". Essa "doutomania estaria difundida em todas as camadas sociais.

$[\ldots]$

Denunciando a "doutomania", Lima Barreto enfatiza o caráter formal do título de ensino superior. A posse do diploma não era garantia de conhecimento, mas seria um "passaporte" para a riqueza, via casamentos de interesse ou via emprego público (LOPES, 2010, p. 73-4).

Assim, se por um lado as múltiplas aplicações do diploma, desde a um casamento vantajoso até a uma colocação em diversas funções no serviço público, poderiam garantir um futuro promissor a um bacharel, as mudanças trazidas pelo positivismo e pela proclamação da República não encontravam mais lugar para esse homem. Nesse momento de transição, tanto a doutomania parecia ser superada, como os novos meios de se sobressair socialmente poderiam também ser questionados.

É importante ressaltar que a produção ficcional e de cronista de Lima Barreto também tem relação com sua experiência individual em uma "cosmovisão essencialmente carioca e brasileira" (MOISÉS, 1996, p. 361). A descoberta tardia de sua obra também pode ser vista como fruto dessas dinâmicas entre conhecimento e ascensão social existentes na capital da República. Assis (2008) aponta esses reflexos na obra de Barreto como algo associado à origem do autor:

Autor de uma vasta obra, só divulgada e reconhecida postumamente, é possível notar que esse literato lutou, muitas vezes sozinho, pelo reconhecimento do povo brasileiro e de sua cidadania, em detrimento de sua origem social, racial ou quaisquer outros preconceitos que, na transição do regime monárquico para o republicano, ou na transição do século XIX para o XX, pudessem vigorar (ASSIS, 2008, p. 12). 
Outros autores também relacionam a sátira de Lima Barreto com uma espécie de rancor por causa da permanência do autor na posição de amanuense até o fim de sua vida, independentemente da capacidade superior denotada em seus escritos, estudados pela academia somente 50 anos após a sua morte (BOSI, 1994; CÂNDIDO, 2008; MOISÉS, 1996).

Na sua narrativa, portanto, ele demonstra conhecer os mecanismos de ascensão social na Belle Époque carioca, mas não se permite contaminar com essa busca pela forma e pelas aparências em detrimento de suas convicções e da afirmação de sua origem.

A análise aqui empreendida mostra como no conto "O homem que falava Javanês" existe uma tentativa de fazer uma crítica a essa sociedade, à doutomania e ao culto à performance - uma busca por se fazer parecer acadêmico em vez de dominar um conhecimento de fato.

\section{LEITOR, 0 TEXTO E 0 MUNDO - FERRAMENTAS DE ANÁLISE}

Existem diversas formas de abordagem ao texto literário, com compreensões distintas acerca de sua criação, função e relação com a realidade. Estabeleceremos aqui algumas balizas para esta análise, a partir das teorias do efeito estético e da criação de mundos ficcionais. É importante para o professor de Língua e Literatura compreender essas relações porque, uma vez que perceba a formação do leitor implícito à obra literária, pode promover o ambiente necessário para a formação do leitor empírico, seu aluno adolescente, leitor em formação. A alegada resistência à leitura pode ser quebrada quando o professor consegue - pela contextualização, solução de dificuldades quanto ao léxico, apresentação visual de elementos distantes espacial e temporalmente do aluno ou outros recursos - aproximar este leitor empírico e o leitor modelo, facilitando a fruição da obra lida.

Ao estudar a mimesis, Erich Auerbach apresenta diversas análises de textos clássicos e romances e nos ensina uma postura de críticos a partir daquilo que o texto nos apresenta como elemento essencial de abordagem, deixando em segundo plano as possíveis intenções autorais ou do leitor:

O método da interpretação de textos deixa à discrição do intérprete dum certo campo de ação: pode escolher e dar ênfase como preferir. Contudo, aquilo que afirma deve ser encontrável no texto. As minhas interpretações são dirigidas, sem dúvida, por uma intenção determinada; mas esta intenção só ganhou forma paulatinamente, sempre durante o jogo com o texto, e durante longos trechos, deixei-me levar pelo texto (AUERBACH, 2015, p. 501). 
Concordamos com o autor quanto a esse fato e buscamos também proceder uma leitura indutiva-construtiva, na qual, a partir daquilo que está sinalizado na materialidade do texto, percorrendo pistas deixadas pelo escritor e dos significados latentes na superfície textual, podemos chegar à enunciação do texto e inferir sentidos.

De acordo com essa escolha metodológica, precisamos fazer algumas distinções quanto às noções de Autor empírico, Autor implícito, Narrador, Narratário, Leitor implícito (ou leitor-modelo) e Leitor empírico. Essas instâncias são constituídas nos polos de escrita e leitura do texto literário e são elementos do próprio processo de ficcionalização. Desse modo, os diversos tipos de autor e leitor são tomados como instâncias separadas: o autor empírico, aquele ser biográfico, que tem sua existência no mundo real, é o responsável pela criação de um autor implícito, uma persona cuja retórica se constitui em estilo e que o distingue dos demais autores. Este autor implícito é aquele que pode ser retomado pela crítica literária, uma vez que, mesmo em aspectos biográficos, o autor empírico continua inacessível aos leitores, pois consideramos que tudo aquilo que ele deixa enquanto marcas de sua existência são, na verdade, máscaras de estilo que se preservam na história. Desse modo, o autor implícito é o responsável por configurar o narrador, aquele que toma a palavra no texto literário e que se dirige diretamente a um narratário.

O autor implícito, ao criar cada narrador e seu(s) narratário(s), tem em mente um leitor implícito (ou leitor-modelo) para quem deixa pistas na leitura. O leitor implícito é aquele a quem o autor se dirige ou que imagina enquanto receptor do seu texto. Ele também é construído pelo autor e teria a capacidade de perceber e atualizar os sentidos presentes no texto, o que nem sempre acontece. O leitor empírico (leitor possível), por sua vez, é aquele que de fato será o responsável pela atualização dos sentidos do texto. Ele pode estar mais próximo (temporal ou espacialmente) do leitor implícito, mas também pode estar muito distante da recepção prevista pelo autor da obra, sendo capaz, inclusive, de perceber sinais nem sempre deixados no texto de maneira intencional pelo autor. Iser (1996) nos alerta quanto a isso:

[...] pensa-se na estrutura do leitor implícito embutida nos textos. À diferença os tipos de leitor referidos, o leitor implícito não tem existência no mundo real; pois ele materializa o conjunto das pré-orientações que um texto ficcional oferece, como condições de recepção a seus leitores possíveis. Em consequência, o leitor implícito não se funda em um substrato empírico, mas sim na estrutura do texto. Se daí inferimos que os textos só adquirem sua realidade ao serem lidos, isso significa que as condições de 
atualização do texto se inscrevem na própria construção do texto, que permitem construir o sentido do texto na consciência receptiva do leitor (ISER, 1996, p. 73).

Essa observação é sobremaneira relevante, pois, mesmo havendo um grande distanciamento do leitor empírico/possível em relação às formas mais contemporâneas de recepção, esta separação não o autoriza a extrair ou impingir ao texto significados que não estejam previstos em sua materialidade. Os perigos da "superinterpretação" também são apontados por Eco (2002; 2004), uma vez que ele também indica a presença do leitor já no momento de concepção da obra literária, e não somente na recepção do texto:

\begin{abstract}
A diferença que nos interessa não passa entre cooperação textual e crítica, mas entre crítica que narra e faz frutificar as modalidades de cooperação textual e crítica que usa o texto, como temos visto, para outros fins [...]. Esta é a crítica que ajuda a realizar a cooperação também lá onde a nossa desatenção a levara a malograr. E é o tipo de crítica que se deverá definir, nos limites do presente discurso, como exemplo de cooperação textual "excelente". Também quando discorda dos resultados da nossa cooperação e se acha o dever de negar ao crítico a função de Leitor-Modelo. Devemos ser-lhe gratos por tê-lo tentado (ECO, 2004, p. 159-60, grifos do autor).
\end{abstract}

Para ele, portanto, a melhor maneira de empreender uma tentativa de "cooperação textual" é exercitar um olhar atento às estruturas demarcadas no próprio texto literário de modo a depreender e configurar um leitor-modelo (leitor implícito, para Iser), que seria "um conjunto de instruções textuais, apresentadas pela manifestação linear do texto precisamente como um conjunto de frases ou de outros sinais" (ECO, 2002, p. 22).

Quando trabalhamos com textos de literatura, é comum procedermos a análise de textos escritos há dezenas ou centenas de anos ou de autores de outras nacionalidades ou regiões. Assim, é preciso ter consciência dessa lacuna da recepção para que não pequemos ao atribuir intenções ao texto que não se relacionam ao seu contexto e nem poderiam ser depreendidas de sua estrutura textual. Há percepções que trazemos para a leitura que decorrem justamente desse distanciamento e de um olhar histórico que não poderia pertencer ao autor empírico, mas também o olhar do crítico pode perceber como a sensibilidade daquele autor às questões de seu contexto são impressas na construção do texto.

O leitor empírico, ao proceder a análise de um texto literário em um tempo e espaço distantes de sua época de produção, também tem condições de perceber de que maneira esse texto constrói um mundo ficcional relacionado com aquele mundo real em que está ancorado. Eco também define como capacidade do texto literário o fato de, pela criação de narrativas ficcionais, sermos capazes 
de acrescentar possibilidades ao mundo real e, dessa maneira, apurar os sentidos para a compreensão da realidade. Um conto ou romance, mesmo sendo um mundo fechado, encerrado nas páginas do texto, passa também a compor o mundo real oferecendo perspectivas de análise de posicionamento a essa realidade:

Por um lado, na medida em que um universo de ficção nos conta a história de algumas poucas personagens em tempo e local bem definidos, podemos vê-lo como um pequeno mundo infinitamente mais limitado que o mundo real. Por outro, na medida em que acrescenta indivíduos, atributos e acontecimentos ao conjunto do universo real (que lhe serve de pano de fundo), podemos considerá-lo maior que o mundo de nossa experiência (ECO, 2002, p. 91).

Italo Calvino (1995), por sua vez, alerta para o fato de que a aproximação do ficcional ao real não tem como ambição a captação ou reprodução da realidade, uma vez que essa apreensão não pode ser feita de modo pleno no texto literário. As vozes que se sobrepõem na narrativa (personagens, narrador(es), autor, escritor) tomam posse dos discursos uns dos outros e os alteram em diversos movimentos de refração. A tomada/criação dessas instâncias de fala mostra como aqueles excertos da realidade se relacionam com a percepção daquele(s) indivíduo(s) acerca dos níveis de realidade apresentados no texto.

[...] la letteratura non conosce la realtà ma solo livelli. Se esista la realtà di cui i vari livelli nonsono che aspetti parziali, o se esistano solo i livelli, quanto a esto la letteratura non può deciderlo. La letteratura conosce forse meglio di quanto non s'arrivi a conoscerla attraverso altri procedimenti conosciviti. È già molto ${ }^{23}$ (CALVINO, 1995, p. 390).

Cabe ao analista, enfim, avaliar a construção de um Mundo Ficcional e como a sua estruturação toca a realidade em algum de seus múltiplos níveis conforme apresentada a esse leitor-modelo, implícito no texto literário, para dali depreender sentido:

O discurso seria o ponto em que viriam a convergir autor e leitor, ou seja, a linguagem, dotada de uma função norteadora, estaria se mostrando como uma maneira de olhar, de proporcionar a interação do homem com o seu mundo, bem como a própria configuração desse mundo enquanto tal. Assim, o olhar do leitor passaria a existir pelo discurso. Diante de cada mundo criado, o homem teria a sensação de apreender na

\footnotetext{
23 A literatura não conhece a realidade, somente os níveis. Se existe a realidade cujos níveis são apenas aspectos parciais, ou se existem apenas os níveis, isto não pode ser decidido pela literatura. A literatura conhece a realidade dos níveis, e esta é uma realidade que conhece talvez melhor do que venhamos a poder conhecê-la por meio de qualquer outro processo cognitivo (Tradução livre do original).
} 
palavra aquilo que aparece diante de si por meio das representações, da significação (ARAUZ, 2009, p. 90).

Essa configuração do olhar acontece em qualquer leitor empírico que se aproxime da obra lida, seja para um momento diletante ou para o estudo do texto. O repertório evocado dependerá dos objetivos de leitura e da vivência de cada indivíduo ao se aproximar de um livro. O que por vezes acontece é a resistência de um leitor à recepção de um texto, principalmente quando este se distancia daquele em muitos anos, por causa da dificuldade em atualizar os sentidos e as relações presentes na narrativa, pensada originalmente para um outro leitor. Cabe ao crítico - que muitas vezes é o professor em uma sala de aula - auxiliar esse leitor na busca pelos sentidos, como em um trabalho de detetive que, ao juntar as pistas encontradas, pode se maravilhar com as possibilidades das relações estabelecidas naquele Mundo Ficcional.

\section{UM "DOUTOR LINGUISTA" NA BELLE ÉPOQUE CARIOCA}

O conto O homem que sabia javanês foi escrito por Lima Barreto e publicado pela primeira vez em 1911, na Gazeta da Tarde, no Rio de Janeiro. Embora já tenha sido abordado por seu caráter irônico (PIRES, 1994; ASSIS, 2008; OLIVER, 2010; JARDIM, 2010), marca inquestionável dessa narrativa a partir de seu título, nesta análise partiremos de uma afirmação que se encontra em suas últimas linhas:

- Olha: se não fosse estar contente, sabes que iria ser?

- Que?

- Bacteriologista eminente. Vamos?

- Vamos.

(BARRETO, 2017, p.10)

Essa afirmação de que o protagonista, se não houvesse ganho a vida fingindo saber um idioma pouco conhecido no Brasil, poderia igualmente fazê-lo como um cientista, sem para tanto obter o conhecimento necessário, chama a atenção do leitor. Assim, a narrativa de todo o sucesso como professor de javanês e linguista, que de modo alegado seria "pra poder viver", fica embaçada pelo que seria a real intenção da personagem: "arranjar belas páginas de vida", "levar uma vida engraçada" e correr "aventuras aqui, neste Brasil imbecil e burocrático" (BARRETO, 2017, p. 4). E isso seria possível como linguista ou como cientista, mas não como bacharel. 
No cenário de uma confeitaria carioca, símbolo de encontros da elite intelectual do país desde o século anterior, Lima Barreto apresenta ao leitor a história de Castelo, um bacharel que, por não obter sucesso profissional e financeiro pela sua formação, entrega-se a uma carreira de "homem de letras". O diálogo é breve e narra eventos em um tempo recente, dada a rapidez com que eles são mencionados. Pode-se inferir que o tempo transcorrido entre o infortúnio e o sucesso de Castelo é de poucos anos, e a conversa entre os interlocutores na mesa dura o tempo de consumo de algumas canecas de cerveja.

É interessante notar a escolha dos nomes dos interlocutores no conto: o narrador protagonista se chama Castelo, enquanto seu narratário/ouvinte, Castro. Tratam-se ambos de sobrenomes tradicionais portugueses, mas se dispostos juntos e em oposição, como acontece no conto, revelam um jogo em que Castro, que significa "castelo antigo", ouve as histórias de Castelo, cujo nome evoca simultaneamente sentidos relacionados ao "sólido" e ao "fugaz", como os "castelos no ar", "castelos de cartas" ou "castelos de areia". Assim, opõem-se a tradição de um ouvinte adaptado às convenções da capital da República e a inovação do modo de vida de um homem que, por não mais conseguir posição na sociedade, se torna dúbio, em uma vida cheia de subterfúgios. De fato, o papel do narratário na história é, por meio de intervenções pontuais, associar-se hipoteticamente ao leitor implícito. Ele faz as perguntas que cobram a verossimilhança das peripécias de Castelo:

- E ele acreditou? E o físico? perguntou meu amigo que até então me ouvira calado (BARRETO, 2017, p. 7).

- Como, se tu nada sabias? interrompeu-me o atento Castro.

$[\ldots]$

- E nunca duvidaram? perguntou-me ainda o meu amigo (BARRETO, 2017, p. 9)

Sobre o "saber" apresentado no título, Oliver (2010) faz uma leitura perspicaz em que aponta a dificuldade desse narrador convencer seu interlocutor acerca de sua malandragem, pois, mesmo afirmando o seu desconhecimento acerca da matéria que lecionava e a sua indisposição para de fato aprender algo sobre o javanês, deixa transparecer em vários momentos do conto que, na verdade, passou por etapas de um aprendizado efetivo (mesmo que talvez insuficiente) do idioma e da cultura javanesa. Apesar de se afirmar malandro em todas as suas falas, as suas ações geralmente o demonstram ambíguo:

Estar autorizado a saber implica que o reconhecimento externo, social, esteja em acordo com a aquisição gradual de um conhecimento, que se torna, ao fim e ao cabo, saber. O que Castelo faz o tempo todo no conto é, na verdade, prevenir que isso acon- 
teça e prevenir o leitor a inferir que na mais remota possibilidade isso venha a acontecer. Se ele tem sucesso em ambas as tarefas é um sucesso, no entanto, relativo. Como determinar quando essa aquisição se completa? Evidente que a exigência, segundo os pressupostos morais do conto, seria a de que Castelo, para legitimar-se enquanto sabedor de javanês, teria que ler, falar, escrever fluentemente a língua javanesa quantum satis. Mas quantos professores sabem tanto? (OLIVER, 2010, p. 223).

A inspiração para essa postura de narrador golpista já é revelada no início do conto: Gil Blas e sua herança picaresca do Lazarillo de Tormes, escrito embrionário do que viria a ser o romance. Para o narrador, a vida de aventuras merece ser narrada em detrimento dos esforços que precisou empreender para adquirir algum conhecimento. A exaltação de um caráter duvidoso também é revelada quando Castelo confessa a perda de qualquer interesse pelo aprendizado quando se vê em uma situação confortável. O pouco conhecimento que obteve se mostrava ser suficiente para manter a vida em suas necessidades mais básicas. Com o emprego do golpe, ele passa de um homem que não tem dinheiro sequer para tomar um bonde a alguém com um emprego vantajoso:

\footnotetext{
Pus-me com afã no estudo das línguas malaio-polinésicas; mas não havia meio!

Bem jantado, bem-vestido, bem dormido, não tinha energia necessária para fazer entrar na cachola aquelas coisas esquisitas (BARRETO, 2017, p. 10).
}

Outra marca que revela um pretenso desprezo ao conhecimento e ao aprendizado do idioma é o uso dos referentes relacionados ao Javanês. Ao longo do conto, Castelo fala da "tal língua malaia", do "idioma oceânico", do "malaio" ou "meu malaio", do "tal javanês", das "línguas malaio-polinésicas", do "jargão das ilhas de sonda" e, de maneira ainda mais pejorativa, do "vasconço" ou da "língua esquisita". Isso se reproduz também ao se referir ao alfabeto como "calungas" ou "“abc'malaio"; à história literária como "histórias bem tolas" e ao livro javanês como "alfarrábio" ou "patuá malaio". Ele despreza no ambiente privado da conversa com seu companheiro o conhecimento simulado que havia the conferido publicamente o sustento e o reconhecimento na sociedade.

$\mathrm{O}$ enredo mostra as etapas percorridas pelo protagonista para, ao fingir dominar um idioma, obter vantagem financeira sobre um barão idoso. Nessa relação também se estabelece uma oposição entre o antigo modo de vida carioca e os novos tempos da República. Castelo é bacharel, mas não consegue se situar profissionalmente na burocracia estatal apenas com essa formação e o Barão de Jacuecanga tem o título de nobreza e um casarão da Tijuca, mas ambos não lhe valem mais como glória ou fortuna, algo denotado na decadência da família e da propriedade. Note-se também a escolha do sobrenome do barão, uma vez que, 
mesmo não correspondendo a nenhum contemporâneo real de Lima Barreto, faz referência à tradição carioca: Manuel Feliciano Soares Albernaz tem em seu nome alusão a famílias portuguesas que têm presença no Rio de Janeiro desde o século XVI.

A menção ao bairro da Tijuca, mormente à rua Conde de Bonfim, realça essa oposição, uma vez que essa região da cidade, após a reconfiguração do Centro pelo prefeito Pereira Passos, se tornaria a próxima a sentir os efeitos da modernização imposta pelos novos tempos. Essa localidade, onde viviam anteriormente os membros da nobreza, começou a se industrializar no início do século XX, sofrendo também uma profunda reconfiguração. Assim, o Barão de Jacuecanga é a tradição sendo ensinada pelo recém-chegado Castelo, detentor de um conhecimento inusitado que será útil a ambos, mesmo sendo falso. Para ambos, também, a relação com o trabalho não se dá de uma forma produtiva, uma vez que o primeiro vive das posses de sua família (a casa, o livro, a herança) e o segundo, do emprego de seus ardis:

A personagem constrói sua imagem reforçando a ideia da tradição do trabalho familiar, embora não tenha uma ocupação definitiva. Convém assinalar que, à época da produção de Barreto, não havia mais espaço para os regalos monárquicos, dos quais o Barão se beneficiou ao largo da vida. A força que movimentava a sociedade já apresentava nucleações urbanas periféricas e ares de industrialização massiva para a época. Portanto, o trabalho pautava-se na produção de riqueza por meio de um sistema produtivo que incluía grande parte da população, porém onde havia os excluídos, como é o caso de Castelo (MÜGGE; CONTE; HENGEN, 2018, p. 171).

A trama efusivamente narrada por Castelo é provocada por um anúncio no Jornal do Commercio, tradicional periódico da capital, em que o Barão de Jacuecanga solicita um professor de língua javanesa para contratação. Movido por suas dívidas e pelo prestígio antevisto em uma conversa com seu senhorio português, o protagonista empreende uma série de etapas para fazer-se passar por esse professor: vai à Biblioteca Nacional, consulta a Grande encyclopédie, esforça-se no aprendizado do alfabeto javanês, depois das estruturas sintáticas e alguns diálogos. Ao ouvir a justificativa do Barão para o aprendizado da língua, Castelo passa a se valer novamente de sua habilidade em inventar histórias para ludibriar seu aprendiz:

[...] Ao fim de dois meses, desistira da aprendizagem e pedira-me que traduzisse, um dia sim outro não, um trecho do livro encantado. Bastava entendê-lo, disse ele; nada se opunha que outrem o traduzisse e ele ouvisse. Assim evitava a fadiga do estudo e cumpria o encargo. 
Sabes bem que até hoje nada sei de javanês, mas compus umas histórias bem tolas e impingi-as ao velhote como sendo do crônicon. Como ele ouvia aquelas bobagens!...

Ficava estático, como se estivesse a ouvir palavras de um anjo. E eu crescia aos seus olhos! (BARRETO, 2017, p. 8).

$\mathrm{O}$ acaso, apontado pelo narrador como elemento motivador em todo o enredo, é alegado como também responsável pelo sucesso financeiro do Barão e consequente recompensa a Castelo. Ele também conduz o restante dos passos do protagonista a uma carreira acadêmica e diplomática:

\footnotetext{
Dentro de um jogo de simulações e de dissimulações em que a imagem do não-trabalho aparece como estratégia de sobrevivência, a personagem percebe a possibilidade de ascensão social, o que de fato se materializa quando consegue, por meio de diversos estratagemas, uma colocação definitiva contexto laboral (MÜGGE; CONTE; HENGEN, 2018, p. 174).
}

Castelo parece ter logrado o sucesso por meio daquilo que pretendeu defender como modo de vida para seu amigo Castro, ou seja, uma vida em que as peripécias se sobrepõem ao ofício cotidiano, este sendo deixado para as pessoas comuns. No entanto, como também observa Oliver (2010), as conquistas podem ser tributadas ao esforço e aos saberes de Castelo. Como exemplo, depreendemos pela narrativa que o bacharel, além de ter uma formação superior em um país onde a poucos isso era possível, conseguia ler e falar o francês e o inglês, tinha um gosto refinado e trânsito fácil nos ambientes de elite que frequentava e foi capaz de produzir trabalhos acadêmicos. Estes últimos são dignos de nota especial, pois é mostrada na narrativa uma tendência para que se valorizassem os aspectos formais do conhecimento, em detrimento do conteúdo apresentado nas publicações apresentadas por Castelo: ele sabe escrever para o Jornal, para publicações científicas, circular em eventos acadêmicos, mesmo que para isso precise fazer publicar falsas notas biográficas e bibliográficas em periódicos e citar "a não mais poder".

Essa performance desprovida de conteúdo é o que parece garantir ao narrador/protagonista que ele seria capaz de transitar em qualquer área acadêmica, desempenhando funções como linguista ou bacteriologista. Lima Barreto, ao sinalizar essa capacidade de Castelo, usa a voz da personagem para denunciar uma postura própria de sua época, conforme a qual os escritores esforçavam-se para apresentar um formalismo excessivo em detrimento do conteúdo apresentado em seus textos. Isso pode ser confirmado pela descrição a seguir do estilo do escritor: 
Uma última ponderação, quanto à linguagem [de Lima Barreto]: espontânea, quase jornalística, descontraída, para se contrapor ao vezo coevo de fazer estilo, de apontar a sintaxe às raias da esterilização, no falso pressuposto de que escrever bem significa obedecer cegamente aos ditames da gramática tradicional, purista e normativa (MOISÉS, 1996, p. 361).

Note-se ainda a referência às pessoas que se deixam impressionar pelo "conhecimento" de Castelo: o senhorio português que, mesmo sendo proprietário de imóvel e bem posicionado socialmente, não parece ter qualquer noção de geografia, mesmo se tratando das colônias de seu povo de que ele parece muito se orgulhar; o desembargador, genro do Barão de Jacuecanga, que usava a proximidade com Castelo e seu saber inigualável como elemento de distinção; os chefes de seção da diplomacia e o próprio ministro de relações internacionais; o presidente do congresso de linguística; e até mesmo o presidente da República.

Concordamos com Figueiredo (2010), quando ela descreve em sua análise do conto essa tendência à valorização da performance nessa sociedade com que Lima Barreto conviveu, na qual não é preciso dominar o conhecimento, mas apenas parecer fazê-lo para gozar prestígio juntamente com seus membros mais destacados:

Rituais de um saber difundido como um verniz superficial e marcado por símbolos exteriores de prestígio e opulência, num país de analfabetos. Da Colônia à República, sofisticam-se os ritos e o saber se reveste de novos títulos, trajes e atitudes para impor autoridade, imprimindo como fetiches categorias externas aos indivíduos. Constrói-se a imagem do saber num espetáculo em graus diversos, desde a sedução da pose, deliberadamente estética, de sisudez,

rigor e compenetração até a violência e o autoritarismo de que se reveste o pseudoconhecimento [...].

O escritor Lima Barreto possui, entre os pontos fortes de sua obra, a crítica ao saber como espetáculo na criação de muitos personagens que ostentam o título de doutor coberto pelo verbalismo oco, adulação e prepotência.

Afinal, o escritor também fora contemporâneo da emergência de uma elite profissional que já incorporara os princípios liberais à sua retórica e passava a adotar um discurso científico-evolucionista como modelo de análise social, transformando o letrado em homem de ciência (FIGUEIREDO, 2010, p. 178-179).

É importante notar que Lima Barreto insere em sua narrativa um personagem que se interpõe e provoca Castelo. Um amanuense desafia o protagonista afirmando que domina, de fato, o canaque, raro idioma melanésio da Nova Caledônia. A reação do funcionário descrita pelo narrador é de ódio. Esse amanuense abomina a conduta de Castelo e isso é deixado perceptível para a personagem que menciona o fato em sua narrativa, para o interlocutor e para 
o leitor. Pelo episódio, pode-se depreender que o conhecimento singular desse homem era real, mas ele jamais havia recebido o mesmo reconhecimento que o falsário detectado diante de si. Essa figura sinaliza o repúdio que Lima Barreto, que também era amanuense, tem pela conduta reprovável de Castelo e pode levar a perceber o sentimento do escritor, que jamais recebera em vida o reconhecimento pelo seu saber legítimo.

O doutor linguista poderia ser igualmente o bacteriologista eminente em uma sociedade na qual se valorizava a aparência e a forma em detrimento da profundidade do conhecimento. Uma vez que aqueles que se deixam encantar por Castelo são desmascarados, para o leitor, é deixada a opção de indignar-se juntamente com o amanuense ou até assumir a posição de Castro. Para este, a história ouvida tem um tom meramente anedótico. Ele não parece se impressionar com as conquistas do amigo e, mesmo quando adjetiva o relato como "fantástico", ele o faz de modo indiferente, como se aquilo fosse um conjunto de episódios pitorescos, talvez porque Castro, castelo forte e antigo, saiba distinguir o real conhecimento e saiba também que Havana não está localizada na Polinésia.

\section{CONSIDERAÇÕES FINAIS}

Lima Barreto viveu em uma época, quando os conhecimentos generalistas e a formação de bacharel estavam perdendo lugar para os novos conhecimentos sistematizados herdados do positivismo. A "doutomania", denunciada em diversas de suas obras, pode ser percebida no conto O homem que sabia javanês em uma tentativa de superação do bacharelismo herdado do tempo do império por uma atitude formalista e cientificista que parece ter se preservado no Brasil não somente naquele período, mas perdurado até os dias atuais.

Na sociedade denunciada pelo autor, o "parecer saber" pode valer mais que o conhecimento em si e ele, homem culto, educado nas melhores bases apesar de sua origem, experimentou pessoalmente as dificuldades por se preservar pleno de suas convicções em um Brasil que valorizava os estratagemas e as trocas de favores.

A partir de uma leitura do conto, percebemos como o narrador mostra naquele contexto o desprezo pelo conhecimento e pelo trabalho e a supervalorização de uma vida burlesca. Isso se dá pelas formas de referenciação, pelas escolhas lexicais e pela sequenciação dos episódios no enredo, como se fossem obras do acaso. No entanto, também é possível perceber alguns esforços empreendidos 
pelo protagonista e a conivência da sociedade como determinantes para o sucesso das empresas narradas.

Lima Barreto evidencia, portanto, como a performance pode se sobressair ao conhecimento quando essa se põe diante de pessoas que não o dominam e abre ao leitor uma janela de observação para que possamos perceber essa realidade quando apresentada em nosso próprio entorno.

$\mathrm{Na}$ sala de aula, cabe questionar aos alunos o quanto eles conseguem ser protagonistas de sua formação e se eles percebem os graus obtidos e almejados como saberes que serão úteis para a sua vida ou somente como meios de ascensão social ou para obtenção de vantagens financeiras. É interessante também questionar o quanto as mudanças na sociedade exigem novos saberes e novas formações e se eles têm consciência de que o aprendizado que eles obtêm hoje deverá ser exigido em carreiras que por vezes ainda nem foram criadas. As provocações de Lima Barreto, na aula de Literatura, podem auxiliar o leitor em uma percepção crítica de um Brasil que ainda valoriza mais o título que o conhecimento, com uma leveza característica da sátira do autor.

\section{REFERÊNCIAS}

ARAUZ, Valéria Angélica Ribeiro. Indivisíveis, intangíveis, impossíveis: mundos ficcionais em I nostri antenati, de Italo Calvino. 2009. 133 f. Tese (doutorado) - Universidade Estadual Paulista, Faculdade de Ciências e Letras de Araraquara, 2009. Disponível em: http://hdl.handle.net/11449/102374.

ASSIS, M. L. Lima Barreto: língua, identidade e cidadania. São Paulo. 2008. 166 f. Tese (doutorado) - Universidade de São Paulo, 2008. Disponível em: https:/teses.usp.br/teses/disponiveis/8/8139/tde-27112009-095056/publico/ LUCIA_MARIA_DE_ASSIS.pdf. Acesso em: 20 fev. 2019.

AUERBACH, Erich. Mimesis: a representação da realidade na literatura ocidental. São Paulo: Perspectiva, 2015.

BARRETO, Lima. O homem que sabia javanês. E-book: Editora Schwarcz e Companhia das Letras, 2017.

BOSI, Alfredo. História concisa da literatura brasileira. $33^{\mathrm{a}}$ ed. São Paulo: Cultrix, 1994.

CALVINO, Italo. I livelli della realtà in letteratura. In: CALVINO, Italo. Una pietra sopra. Milano, Italia: Mondadori, 1995. 
CÂNDIDO, Antônio. Literatura e sociedade: estudos de teoria e história literários. Rio de Janeiro: Ouro sobre Azul, 2008.

ECO, Umberto. Seis passeios pelos bosques da ficção. São Paulo: Companhia das Letras, 2002.

ECO, Umberto. Lector in fabula: a cooperação interpretativa nos textos narrativos 2.ed. São Paulo: Perspectiva, 2004.

FIGUEIREDO, Carmem L. N. O romance como experiência cultural: o diálogo crítico de Lima Barreto. Crítica Cultural, v. 5, n.1, jul. 2010. p. 164-185. Disponível em: http://www.portaldeperiodicos.unisul.br/index.php/Critica Cultural/article/view/212/214. Acesso em: 17 abr. 2020.

ISER, Wolfgang. O ato de ler: a teoria do efeito estético. São Paulo: Editora34, 1996.

JARDIM, M. Como simular conhecimento: insinuações literárias. Revista Crioula, n. 7, 1 maio 2010. Disponível em: https://doi.org/10.11606/issn.19817169.crioula.2010.55241. Acesso em: 14 abr. 2020.

LOPES, Silvana Fernandes. A contribuição de Lima Barreto para o entendimento da crítica educacional brasileira do início do século XX. SÆCULUM - Revista de História [22], João Pessoa, jan./jun. 2010, p. 69-84.

MAINGUENEAU, Dominique. Elementos de linguística para o texto literário. São Paulo: Martins Fontes, 1996.

MOISÉS, M. A Literatura brasileira através dos textos. 19.ed. São Paulo, Cultrix, 1996.

MUECKE, D. C. Ironia e o irônico. São Paulo: Perspectiva, 1995.

MÜGGE, Ernani; CONTE, Daniel; HENGEN, Liandra Fátima. Teoria do Medalhão e $\mathrm{O}$ homem que sabia javanês: as faces do (não) trabalho no Brasil no limiar dos séculos XIX e XX. CES Revista, [S.1.], v. 32, n. 2, dez. 2018. ISSN 1983-1625. Disponível em: https://seer.cesjf.br/index.php/cesRevista/article/ view/1710. Acesso em: 17 abr. 2020.

OLIVER, Élide V. O saber em "O homem que sabia javanês, de Lima Barreto". Revista USP, São Paulo, n. 87, p. 214 224, set./nov. 2010.

PAULA JÚNIOR, Josias de. Lima Barreto: crítica literária e marginalidade social. In: ABRALIC, Anais. 2017. p. 211-220. Disponível em: http://www. abralic.org.br/anais/arquivos/2017_1522165732.pdf Acesso em: 17 abr. 2020. 
PIRES, Antônia C. A. A ironia e a crítica social em "O homem que sabia Javanês", de Lima Barreto. Cadernos de Pesquisa da UFMG. n. 16. 1994. Disponível em: https://periodicos.ufmg.br/index.php/cadernos_pesquisa/article/view/11409. Acesso em: 17 abr. 2020.

SONTAG, R. Triatoma baccalaureatus: sobre a crise do bacharelismo na Primeira República. Espaço Jurídico Journal of Law, 9(1), 2008. p. 67-78. Disponível em: $\quad$ http://portalperiodicos.unoesc.edu.br/espacojuridico/article/view/1906. Acesso em: 14 abr. 2020. 
